\title{
GAMBARAN DISTRIBUSI SPESIES Anopheles DAN PERANNYA SEBAGAI VEKTOR MALARIA DI PROVINSI NUSA TENGGARA TIMUR, PAPUA DAN PAPUA BARAT
}

\author{
Vivin Mahdalena1*, Tri Wurisastuti ${ }^{2}$ \\ ${ }^{1}$ Balai Penelitian dan Pengembangan Kesehatan Baturaja \\ Jl. A.Yani KM.7 Kemelak Baturaja, Ogan Komering Ulu, 32111 Sumatera Selatan, Indonesia \\ 2Puslitbang Upaya Kesehatan Masyarakat \\ Badan Litbang Kesehatan, Jl. Percetakan Negara No. 29 Jakarta Pusat, Indonesia
}

\begin{abstract}
Malaria is a mosquito-borne disease that is still a leading cause of death in developing countries. Malaria is also endemic in most parts of Indonesia, especially in eastern Indonesia. The provinces of Indonesia with the highest annual parasite incidence (API) per 1000 population in 2018 are East Nusa Tenggara (NTT), Papua and West Papua. Knowledge and understanding of the Anopheles mosquito as a malaria vector at its location is very important to the optimal control of malaria vector intervention program. This article is a study of literature where information was conducted through books, research articles or scientific journals, and research reports from 2003 to 2019. Anopheles that have been found in NTT, Papua and West Papua Provinces, were An. vagus, An. barbirostris, An. subpictus, An. sundaicus, An. indefinitus, An. tesselatus, An. maculatus, An. aconitus, An. kochi, An. minimus, An. annularis, An. flavirostris, An. umbrosus, An. annulipes, An. farauti, An. barbumbrosus, An. ludlowae, An. punctulatus, An. aitkenii, An. longirostris, An. peditaeniatus, An. koliensis, An. bancrofti, An. hinesorum, and An. meraukensis. Anopheles that have been confirmed as a malaria vector were An. barbirostris, $\overline{A n}$. subpictus, An. sundaicus, An. flavirostris, An. minimus, An. farauti, An. punctulatus and An. longirostris. The host preference of Anopheles that were malaria vectors is more likely to be anthropophilic.
\end{abstract}

Keywords: Spesies, Anopheles, malaria vector, East Nusa Tenggara, Papua, West Papua.

\section{REVIEW OF Anopheles SPECIES AND ITS MALARIA VECTOR STATUS IN EAST NUSA TENGGARA, PAPUA AND WEST PAPUA PROVINCES}

\begin{abstract}
Abstrak
Malaria merupakan penyakit tular nyamuk yang masih menjadi penyebab utama kematian di negara berkembang. Malaria juga masih endemis di sebagian besar wilayah Indonesia, terutama di daerah Indonesia bagian Timur. Tiga provinsi di Indonesia dengan annual parasite incidence (API) tertinggi per 1000 penduduk pada tahun 2018 yaitu Nusa Tenggara Timur (NTT), Papua dan Papua Barat. Pengetahuan dan pemahaman mengenai nyamuk Anopheles sebagai vektor malaria di lokasi penyebarannya sangat penting dalam program intervensi pengendalian vektor malaria yang optimal. Artikel ini merupakan studi literatur dimana informasi diperoleh dari buku, artikel penelitian atau jurnal ilmiah, dan laporan hasil penelitian dari rentang tahun 2003 sampai tahun 2019. Anopheles yang ditemukan di Provinsi NTT, Papua dan Papua Barat yaitu An. vagus, An. barbirostris, An. subpictus, An. sundaicus, An. indefinitus, An. tesselatus, An. maculatus, An. aconitus, An. kochi, An. minimus, An. annularis, An. flavirostris, An. umbrosus, An. annulipes, An. farauti, An. barbumbrosus, An. ludlowae, An. punctulatus, An. aitkenii, An. longirostris, An. peditaeniatus, An. koliensis, An. bancrofti, An. hinesorum, dan An. meraukensis. Anopheles yang sudah terkonfirmasi sebagai vektor malaria yaitu An. barbirostris, An. subpictus, An. sundaicus, An. flavirostris, An. minimus, An. farauti, An. punctulatus dan An. longirostris. Perilaku kesukaan mengisap darah dari beberapa Anopheles yang menjadi vektor malaria lebih cenderung bersifat antropofilik.
\end{abstract}


Kata kunci : Spesies, Anopheles, vektor malaria, Nusa Tenggara Timur, Papua, Papua Barat.

*Alamat korespondensi penulis pertama: e-mail: mahdalenavivin@gmail.com; Telp: (0735) 325303

\section{PENDAHULUAN}

Malaria adalah salah satu diantara penyakit tular nyamuk yang menjadi perhatian utama di Indonesia. Selain berkaitan dengan morbiditas dan mortalitas penduduk, malaria juga berdampak terhadap produktivitas manusia, serta kualitas generasi yang lahir dari ibu hamil penderita malaria. ${ }^{1}$ Malaria pada manusia disebabkan oleh infeksi satu atau beberapa spesies Plasmodium, yang ditularkan melalui gigitan nyamuk Anopheles betina. Spesies Plasmodium falciparum dan Plasmodium vivax menyebabkan infeksi terbanyak di seluruh dunia. Spesies $P$. falciparum sering menyebabkan malaria berat dan menyebabkan kematian, sedangkan $P$. vivax dan $P$. ovale memiliki tahap dorman di hati yang inaktif, serta dapat aktif kembali menyebabkan malaria beberapa bulan atau beberapa tahun setelah infeksi awal. ${ }^{2}$

Malaria termasuk penyakit yang ikut bertanggung jawab terhadap tingginya angka kematian di banyak negara di dunia. Malaria telah berhasil dibasmi sejak tahun 1950 di hampir seluruh benua Eropa, Amerika Tengah dan Selatan, tetapi di beberapa bagian benua Afrika dan Asia Tenggara, penyakit ini masih menjadi masalah besar. Sekitar 100 juta kasus penyakit malaria terjadi setiap tahunnya, satu persen diantaranya berakibat fatal. Malaria seperti kebanyakan penyakit tropis lainnya merupakan penyebab utama kematian di negara berkembang. Penyebaran malaria juga cukup luas di banyak negara, termasuk Indonesia. Malaria juga masih endemis di sebagian besar wilayah Indonesia. Angka kesakitan penyakit ini pun masih cukup tinggi, terutama di daerah Indonesia bagian Timur. $^{3}$

Angka kesakitan malaria secara nasional selama tahun 2009-2018 cenderung menurun yaitu 1,8 per 1000 penduduk pada tahun 2009 menjadi 0,84 per 1000 penduduk pada tahun 2018 . Annual parasite incidence (API) di wilayah Indonesia bagian Timur lebih tinggi dibandingkan wilayah Indonesia bagian Barat. Tiga provinsi di Indonesia dengan API tertinggi per 1000 penduduk pada tahun 2018 yaitu Papua $(41,31)$ dengan jumlah kabupaten/kota endemis tinggi sebanyak 16 kabupaten/kota, Papua Barat $(7,95)$ dengan jumlah kabupaten/kota endemis tinggi sebanyak 5 kabupaten/kota, dan Nusa Tenggara Timur $(3,36)$ dengan jumlah kabupaten/kota endemis tinggi sebanyak 4 kabupaten/kota. Provinsi yang kabupaten/kotanya belum satupun mencapai eliminasi malaria ada di wilayah Indonesia Timur, yaitu Papua, Papua Barat, Nusa Tenggara Timur (NTT), Maluku dan Maluku Utara. ${ }^{4}$

Vektor malaria adalah nyamuk Anopheles dan sampai saat ini sudah ada 90 spesies Anopheles yang ditemukan di Indonesia. Sebanyak 25 spesies Anopheles sudah terkonfirmasi sebagai vektor malaria di beberapa daerah. ${ }^{5}$ Nyamuk Anopheles yang terbukti sebagai vektor malaria di Indonesia bagian Timur adalah An. bancrofti, An. koliensis, An. farauti, An. subpictus, An. barbirostris, An. sundaicus, An. punctulatus dan yang berpotensi sebagai vektor yaitu An. vagus. ${ }^{6}$ Penyebaran Anopheles di wilayah Indonesia bersifat lokal spesifik artinya spesies Anopheles yang ditemukan di suatu wilayah dipengaruhi oleh kespesifikan habitat perkembangbiakannya. ${ }^{7}$ Pola penyebaran Anopheles ditentukan oleh faktor lingkungan, zoogeografi, dan ekosistem. Anopheles di Indonesia tersebar hampir di semua wilayah provinsi, dimana setiap wilayah memiliki kondisi geografi, topografi dan iklim yang berbeda. ${ }^{6}$

$$
\text { Upaya pengendalian nyamuk }
$$
Anopheles yang merupakan vektor malaria 
perlu dilakukan selain dengan tindakan pengobatan terhadap penderita. Hal ini merupakan usaha yang penting untuk menurunkan kasus malaria. Pelaksanaan pengendalian vektor akan efektif dan efisien apabila didukung oleh informasi mengenai vektornya. ${ }^{8}$ Pengetahuan dan pemahaman mengenai nyamuk Anopheles sebagai vektor malaria di lokasi penyebarannya sangat penting dalam program intervensi pengendalian vektor. ${ }^{6}$ Kesesuaian antara perilaku vektor selaku sasaran dan metode pengendalian yang diterapkan akan memberi hasil maksimal pada pengendalian vektor. $^{1}$

Artikel ini menyajikan informasi tentang spesies Anopheles yang tersebar di wilayah Indonesia Timur khususnya Provinsi Papua, Papua Barat dan NTT. Pemilihan tiga provinsi ini berdasarkan wilayah yang masih dalam kategori endemis tinggi malaria dengan API yang paling tinggi. Informasi yang disajikan diharapkan dapat memberikan pengetahuan, gambaran dan pemahaman tentang spesies Anopheles, perilaku mengisap darah dan beristirahat serta habitat perkembangbiakannya yang ditemukan di Provinsi Papua, Papua Barat dan NTT sehingga bisa membantu dalam membuat kebijakan dan program intervensi pengendalian vektor malaria.

\section{METODE}

Artikel ini merupakan studi kepustakaan (literatur) dimana informasi diperoleh dari buku, artikel penelitian atau jurnal ilmiah, dan laporan hasil penelitian dari rentang tahun 2003 sampai tahun 2019. Penelusuran online menggunakan google, googlescholar, researchgate.net, dan media.neliti.com. Kata kunci yang digunakan dalam penelusuran yaitu malaria, Anopheles, Indonesia Timur, bionomik, habitat perkembangbiakan, NTT, Papua dan Papua Barat.

\section{HASIL}

Tabel 1 menggambarkan spesies Anopheles yang ditemukan di Provinsi NTT, Papua dan Papua Barat dari beberapa hasil penelitian yang pernah dilakukan di ketiga provinsi tersebut.

Tabel 1. Spesies Anopheles di Provinsi Nusa Tenggara Timur, Papua, dan Papua Barat

\begin{tabular}{llccc}
\hline & & & Provinsi & \\
\cline { 3 - 5 } No. Spesies Anopheles & & $\mathrm{NTT}^{8,9,10}$ & Papua Barat $^{11,12}$ & Papua $^{13,14,15}$ \\
\hline 1. & An. vagus & $\sqrt{ }$ & $\sqrt{ }$ \\
2. & An. barbirostris & $\sqrt{ }$ & $\sqrt{ }$ \\
3. & An. subpictus & $\sqrt{ }$ & \\
4. & An. sundaicus & $\sqrt{ }$ & \\
5. & An. indefinitus & $\sqrt{ }$ & \\
6. & An. tesselatus & $\sqrt{ }$ & \\
7. & An. maculatus & $\sqrt{ }$ & & \\
8. & An. aconitus & $\sqrt{ }$ & \\
9. An. kochi & An. minimus & $\sqrt{ }$ & \\
10. & $\sqrt{ }$ & \\
11. An. annularis & $\sqrt{ }$ & \\
12. An. flavirostris & $\sqrt{ }$ & \\
\hline
\end{tabular}




\begin{tabular}{|c|c|c|c|c|}
\hline \multirow{2}{*}{ No. } & \multirow{2}{*}{ Spesies Anopheles } & \multicolumn{3}{|c|}{ Provinsi } \\
\hline & & NTT & Papua Barat & Papua \\
\hline 13. & An. umbrosus & $\sqrt{ }$ & & \\
\hline 14. & An. annulipes & & $\sqrt{ }$ & \\
\hline 15. & An. farauti & & $\sqrt{ }$ & $\sqrt{ }$ \\
\hline 16. & An. barbumbrosus & & $\sqrt{ }$ & \\
\hline 17. & An. ludlowae & & $\sqrt{ }$ & \\
\hline 18. & An. punctulatus & & $\sqrt{ }$ & $\sqrt{ }$ \\
\hline 19. & An. aitkenii & & $\sqrt{ }$ & \\
\hline 20. & An. longirostris & & $\sqrt{ }$ & $\sqrt{ }$ \\
\hline 21. & An. peditaeniatus & & $\sqrt{ }$ & \\
\hline 22. & An. koliensis & & $\sqrt{ }$ & $\sqrt{ }$ \\
\hline 23. & An. bancrofti & & & $\sqrt{ }$ \\
\hline 24. & An. hinesorum & & & $\sqrt{ }$ \\
\hline 25. & An. meraukensis & & & $\sqrt{ }$ \\
\hline
\end{tabular}

\section{BAHASAN}

Ekosistem dapat terbentuk dari adanya pengaruh lingkungan seperti kelembaban, suhu lingkungan, vegetasi, dan kondisi peruntukan lahan yang mengubah ekosistem alami menjadi ekosistem buatan. Akibat terbentuknya ekosistem, terdapat berbagai macam spesies salah satunya adalah Anopheles yang berperan sebagai vektor malaria yang hidup karena kondisi lingkungan yang mendukung..$^{16}$ Keberadaan nyamuk malaria di suatu daerah sangat tergantung pada lingkungan, keadaan wilayah seperti perkebunan, keberadaan pantai, curah hujan, kecepatan angin, suhu, sinar matahari, ketinggian tempat dan bentuk perairan yang ada. ${ }^{17}$

Anopheles merupakan salah satu jenis nyamuk yang dapat dibedakan dari jenis nyamuk lainnya karena mempunyai palpus dan probosis yang sama panjang, selain itu cara membedakannya dari nyamuk lain yaitu mengamati posisi istirahat dan mengisap darahnya dengan cara mengangkat abdomen bagian belakangnya. Anopheles betina membutuhkan darah untuk perkembangan telurnya. Saat berlangsungnya pengambilan darah terjadi hubungan antara parasit penyebab malaria, nyamuk sebagai pembawa, dan manusia sebagai penderitanya. ${ }^{18}$

\section{Anopheles vagus}

Anopheles vagus termasuk spesies Anopheles yang hampir tidak memiliki preferensi tersendiri terhadap habitat perkembangbiakannya. Larva nyamuk ini bisa ditemukan di habitat yang natural maupun buatan manusia. Beberapa penelitian menunjukkan $A n$. vagus merupakan spesies yang paling umum ditemukan di semua habitat Anopheles. Spesies ini biasanya ditemukan di air yang tenang atau mengalir lambat dan disinari matahari langsung. ${ }^{19}$ Penelitian yang dilakukan di tiga tipe ekosistem (pantai, dataran rendah, dataran tinggi) di NTT menyebutkan nyamuk ini ditemukan di semua tipe ekosistem tersebut. ${ }^{20}$ Habitat perkembangbiakan An. vagus yaitu kolamkolam kecil di dekat pantai, mata air, saluran irigasi, bekas/tapak roda, sumur, parit, sawah, sungai, tambak, lagun, dan kobakan. Anopheles vagus cenderung bersifat zoofilik atau lebih menyukai darah hewan. Penelitian di Desa Lifuleo, Kabupaten Kupang dan Desa Konda Maloba, Kabupaten Sumba Tengah, NTT, menemukan nyamuk ini lebih banyak tertangkap di sekitar kandang ternak, bersifat eksofagik dan eksofilik atau lebih menyukai mengisap darah dan beristirahat di luar rumah..$^{8,9,19}$ 


\section{Anopheles barbirostris}

Anopheles barbirostris sebagai vektor malaria di wilayah Indonesia ditemukan di Sumatera Utara, Sumatera Selatan, Sulawesi Tengah, ${ }^{13}$ Flores Tengah, Sulawesi Selatan, Sulawesi Tenggara, dan NTT. ${ }^{18}$ Penelitian di Kabupaten Kupang, NTT, An. barbirostris ditemukan mengisap darah sepanjang malam dari pukul 18.0006.00 , puncak mengisap darah terjadi pada pukul 21.00-04.00 baik di dalam maupun di luar rumah. ${ }^{8}$ Penelitian lain di Kabupaten Kupang, Dusun Tuadale, nyamuk ini ditemukan mengisap darah di luar rumah saat siang hari di tempat pemeliharan ikan bandeng. ${ }^{21} \mathrm{Di}$ Sulawesi, NTT dan Timor Timur, An. barbirostris lebih banyak tertarik mengisap darah manusia (antropofilik). Anopheles barbirostris memiliki perilaku antropofilik, zoofilik dan beristirahat di dalam rumah (endofilik). Berdasarkan penelitian di Kabupaten Sikka Flores, An. barbirostris lebih banyak beristirahat di dalam rumah dan kandang, serta mulai mengisap darah begitu malam tiba dan secara berangsur-angsur menurun menjelang subuh. ${ }^{22}$ Habitat perkembangbiakan nyamuk ini terdapat pada dataran rendah, perbukitan dan pegunungan. Habitat perkembangbiakan di wilayah pergunungan adalah persawahan, kobakan, dan terpapar sinar matahari, di wilayah pantai adalah bekas kolam, kubangan dan kobakan, tidak terpapar sinar matahari langsung. Habitat perkembangbiakan yang lain yaitu mata air, kolam, saluran/selokan dan rawa-rawa. Larva An. barbirostris dapat ditemukan pada air keruh maupun jernih. ${ }^{8,22}$

\section{Anopheles subpictus}

$$
\text { Anopheles subpictus telah }
$$

dikonfirmasi sebagai vektor malaria di Provinsi NTT. Penelitian di Pulau Sumba, spesies ini ditemukan mengisap darah sepanjang malam dan banyak tertangkap mengisap darah dan beristirahat di luar rumah terutama di kandang ternak. ${ }^{10}$ Perilaku An. subpictus yang ditemukan di Tanjung Bunga, Flores Timur, puncak mengisap darah nyamuk ini terjadi pada pukul 20.00-22.00. Di Desa Lifuleo, NTT, An. subpictus ditemukan pada dua jenis habitat, yaitu rawa-rawa dan kolam ikan (mujair dan bandeng). Berbeda dengan di daerah pantai
Banyuwangi, An. subpictus ditemukan hanya di mata air. ${ }^{8}$ Habitat perkembangbiakan An. subpictus bervariasi, larva dapat hidup di air jernih maupun air keruh, di air tawar maupun air payau. Larva An.subpictus sering ditemukan bersama dengan larva $A n$. sundaicus di laguna dan bersama $A n$. aconitus di persawahan. ${ }^{23}$

\section{Anopheles sundaicus}

Nyamuk An.sundaicus di Indonesia pada umumnya aktif mengisap darah sepanjang malam dengan kepadatan tertinggi pada tengah malam dan menjelang pagi hari. ${ }^{24}$ Anopheles sundaicus merupakan salah satu spesies Anopheles yang dinyatakan sebagai vektor malaria di Provinsi NTT. Nyamuk ini memegang peranan penting dalam penyebaran malaria dimana sering ditemukan di daerah pantai. Anopheles sundaicus biasanya berkembang biak di air payau, yaitu campuran air tawar dan air asin, dan larvanya senang pada sinar matahari (heliofilik). Habitat perkembangbiakan An. sundaicus yang terdapat di Desa Konda Maloba, NTT berupa aliran air. ${ }^{25}$ Anopheles sundaicus betina mengisap darah manusia atau hewan, namun lebih cenderung mengisap darah manusia, aktif mencari makan pada malam hari, pada umumnya malam hari mulai senja hingga pagi dengan puncak gigitan yang berbeda. Kebiasaan tempat mengisap darah An. sundaicus cenderung eksofagik dan istirahat cenderung endofilik. Penelitian di Kabupaten Kupang, menunjukkan bahwa pada ekologi pantai nyamuk $A n$. sundaicus cenderung bersifat eksofagik. ${ }^{10,25}$

\section{Anopheles maculatus}

Anopheles maculatus telah dikonfirmasi sebagai vektor di daerah pulau Jawa. Nyamuk ini banyak tertangkap mengisap darah dan istirahat di luar rumah, terutama pada kandang ternak, dan juga lebih menyukai mengisap darah hewan. ${ }^{10,26}$ Anopheles maculatus senang berkembangbiak pada tempat yang langsung mendapat sinar matahari. Habitat perkembangbiakan An. maculatus berupa genangan air, pada tepi sungai, rembesan dan sawah yang airnya mengalir lambat. ${ }^{9}$ Penelitian di Desa Polowangi, Kabupaten Purworejo, Jawa Tengah, populasi nyamuk 
An. maculatus menyebar ke berbagai tempat baik di dalam rumah, di luar rumah ataupun di kebun, dan lebih banyak ditemukan di semak-semak. Habitat perkembangbiakan An. maculatus berada di tepi sungai, namun nyamuk akan terbang ke arah permukiman di perbukitan. Kemungkinan An. maculatus memanfaatkan semak-semak untuk tempat istirahat sebelum mencari mangsanya. Habitat An. maculatus yang dekat permukiman penduduk berupa genangan mata air yang banyak terdapat di sela-sela bukit batu cadas. Aktivitas mengisap darah $A n$. maculatus lebih banyak di luar rumah atau bersifat eksofagik. Di Jawa Barat, An. maculatus beristirahat di kandang ternak dan sekitar perkebunan sawit dan kopi di siang hari. ${ }^{27}$ Penelitian di Kecamatan Srumbung, Kabupaten Magelang, Jawa Tengah, An. maculatus ditemukan beristirahat di lubang tanah pada tebing di kebun salak pada pagi hari dan sisanya ditemukan di serasah daun salak. ${ }^{28}$

\section{Anopheles aconitus}

Anopheles aconitus merupakan nyamuk yang diduga sebagai vektor di NTT, namun telah terbukti sebagai vektor di daerah pulau Jawa. Aktivitas mengisap darah An.aconitus dimulai pada pukul 19.00-04.00, dengan puncak kepadatan pukul 20.00-21.00, beristirahat di luar rumah di sekitar kandang ternak, cenderung eksofagik dan eksofilik. ${ }^{26}$ Anopheles aconitus merupakan spesies yang aktivitas mengisap darah pada setiap jam penangkapan sampai pada pagi hari, dan beristirahat di luar maupun di dalam rumah. 9,10 Anopheles aconitus suka mengisap darah manusia dan hewan, namun lebih cenderung mengisap darah hewan. Nyamuk ini ditemukan hingga mencapai ketinggian mencapai 850 meter di atas permukaan air laut. Anopheles aconitus senang berkembang biak di air yang tenang atau sedikit mengalir seperti sawah. Habitat perkembangbiakan An. aconitus yang ditemukan di Kabupaten Sumba Tengah yaitu aliran air, sedangkan daerah pantai ditemukan di Kabupaten Kupang. ${ }^{9}$

\section{Anopheles kochi}

Anopheles kochi berperan sebagai vektor malaria di Sumatera dan Sulawasi. ${ }^{29}$ Perilaku An. kochi pada penelitian di Sumba Tengah ditemukan hanya mengisap darah dan beristirahat di luar rumah, yaitu di kandang ternak. ${ }^{9,26}$ Penelitian di Pulau Sumba pada tahun 2009 dan 2012, An. kochi juga ditemukan hanya mengisap darah dan beristirahat di luar rumah. Kenyataan ini menunjukkan bahwa nyamuk setelah mengisap darah akan lebih banyak beristirahat sementara di luar rumah sebelum mencari habitat untuk berkembang biak. ${ }^{10}$ Penelitian yang dilakukan oleh Barodji di Kabupaten Kulonprogo, Yogyakarta, menemukan bahwa rata-rata An. kochi beristirahat di luar rumah lebih tinggi dibandingkan di dalam rumah. ${ }^{30}$ Habitat perkembangbiakan An. kochi yaitu kobakan, sungai kecil, sawah, kolam, selokan dan genangan air. ${ }^{26} \mathrm{Di}$ Provinsi Papua Barat, Kabupaten Manokwari dan Raja Ampat, An. kochi ditemukan pada ekosistem hutan dekat permukiman dan non hutan dekat permukiman dengan umpan ternak dan animal bait trap (ABT). ${ }^{11}$

\section{Anopheles indefinitus}

Nyamuk $A n$. indefinitus mempunyai perilaku mengisap darah dan beristirahat di dalam dan luar rumah, namun lebih banyak tertangkap di luar rumah.8,9 Penelitian di Kabupaten Sumba Tengah, nyamuk ini hanya ditemukan tertangkap beristirahat di luar rumah yaitu di kandang ternak. ${ }^{26}$ Nyamuk An. indefinitus memiliki puncak kepadatan mengisap darah di dalam rumah antara pukul 20.00-21.00, dan di luar rumah antara pukul 24.00-03.00. ${ }^{8}$ Larva An. indefinitus ditemukan pada habitat sungai dengan air yang jernih, saluran irigasi, persawahan, kobakan, kubangan kerbau, selokan, rawa, lagun, sumur, lubang akar pohon kelapa, genangan air pada perahu, pijakan kaki, dan selokan. ${ }^{9,26,31}$

\section{Anopheles annularis}

Nyamuk An. annularis mengisap darah di dalam dan di luar rumah dan beristirahat di dalam dan di luar rumah terutama di sekitar kandang ternak. ${ }^{8,10}$ Puncak kepadatan mengisap darah orang di dalam rumah antara pukul 23.00-24.00 dan pukul 02.00-03.00, sedangkan di luar 
rumah antara pukul 19.00-20.00 dan pukul 02.00-03.00.8 Penelitian di Desa Konda Maloba, nyamuk ini tidak ditemukan mengisap darah di dalam maupun di luar rumah dan hanya ditemukan beristirahat di sekitar kandang ternak, begitu juga pada penelitian yang dilakukan di Desa Wagirpandan Kabupaten Kebumen. Habitat perkembangbiakan An. annularis yaitu sawah dan pantai. ${ }^{9,32}$ Penelitian di Desa Selong Belanak, Kabupaten Lombok Tengah, An. annularis ditemukan mengisap darah di dalam rumah dan beristirahat di sekitar kandang ternak. ${ }^{33}$

\section{Anopheles flavirostris}

Anopheles flavirostris di beberapa daerah diketahui sebagai vektor malaria di NTB, NTT, Sumatera Utara dan Sulawesi Selatan. ${ }^{34}$ Nyamuk ini ditemukan mengisap darah di dalam dan di luar rumah, serta beristirahat di dalam rumah dan tidak ditemukan beristirahat di luar rumah atau di sekitar kandang ternak. ${ }^{9,10}$ Penelitian di Kabupaten Sumba Tengah, An. flavirostris ditemukan tertangkap di sekitar kandang ternak, tidak ditemukan mengisap darah di dalam maupun di luar rumah, dan juga tidak ditemukan beristirahat di dalam rumah. ${ }^{26}$ Nyamuk An.flavirostris biasanya berada di kaki gunung, di Pulau Jawa nyamuk ini biasa ditemukan di daerah hutan atau juga di kolam. Hasil penelitian di Desa Ranoketang Tua, Kabupaten Minahasa Selatan, menunjukkan puncak aktivitas mengisap darah An. flavirostris terjadi pada pukul 18.00-19.00, 20.00-21.00, 23.0024.00 dan 04.00-05.00. ${ }^{35}$ Penelitian di Desa Jladri dan Desa Jintung Kabupaten Kebumen, An. flavirostris mulai muncul pada pukul 19.00-02.00 WIB, puncak kepadatan terjadi pada pukul $23.00-24.00$ WIB. ${ }^{34}$

\section{Anopheles tesselatus}

Di Pulau Sumba, An. tesselatus ditemukan mengisap darah dan beristirahat di dalam maupun di luar rumah, tetapi lebih dominan ditemukan beristirahat di luar rumah di sekitar kandang ternak. ${ }^{10}$ Penelitian di Kabupaten Sumba Tengah, An. tesselatus ditemukan tertangkap beristirahat di sekitar kandang ternak, tidak ditemukan beristirahat di dalam rumah maupun mengisap darah di dalam dan luar rumah. ${ }^{26}$
Anopheles tessellatus lebih cenderung mencari darah hewan ketimbang darah manusia. ${ }^{35}$ Penyebaran An. tesselatus di Provinsi Papua Barat yaitu ditemukan pada ekosistem hutan dekat permukiman, non hutan dekat permukiman dan non hutan jauh permukiman. Nyamuk ini tertangkap mengisap darah di luar rumah dan dalam rumah, serta penangkapan dengan umpan ternak. ${ }^{11}$ Penelitian di Kabupaten Jayapura, Provinsi Papua, An. tesselatus lebih bersifat zoofilik dan ditemukan pada penangkapan dengan umpan hewan ternak. ${ }^{15}$ Larva $A n$. tesselatus ditemukan di kobakan, sungai kecil, sawah dan genangan air. ${ }^{26,36}$

\section{Anopheles umbrosus}

Nyamuk An. umbrosus mempunyai perilaku mengisap darah dan beristirahat di dalam dan di luar rumah. Separuh populasinya ditemukan di luar rumah dan sebagian besar ditemukan di kandang sapi. Nyamuk ini juga ditemukan pada penangkapan dengan perangkap cahaya. Puncak kepadatan mengisap darah An. umbrosus di dalam rumah dimulai pukul 20.00-21.00 dan pukul 24.00-03.00, dan di luar rumah pukul 22.00-23.00.8 Di Desa Emparu dan Mangat Baru, Provinsi Kalimantan Barat, An. umbrosus ditemukan mengisap darah dan beristirahat di dalam maupun di luar rumah, tetapi lebih banyak ditemukan di sekitar kandang ternak. Puncak aktivitas An. umbrosus mencari darah atau mengisap darah yaitu pada pukul 19.00-23.00. Habitat perkembangbiakan An. umbrosus biasanya terdapat di rawa yang disekitarnya banyak terdapat pohon atau hutan lebat, ${ }^{37}$ dan tidak menyukai habitat perkembangbiakannya terkena sinar matahari secara langsung. ${ }^{33}$

\section{Anopheles minimus}

Nyamuk An.minimus dikonfirmasi sebagai vektor malaria di Provinsi NTT. Nyamuk ini mengisap darah dan beristirahat di dalam maupun di luar rumah, terutama beristirahat di sekitar kandang. ${ }^{10}$ Penelitian di Desa Datar Luas, Provinsi Aceh, An. minimus hanya ditemukan mengisap darah manusia di luar rumah. Aktivitas mengisap darah nyamuk ini terjadi dari pukul 01.0003.00. ${ }^{38}$ Perilaku An.minimus berbeda dengan yang ditemukan di Kecamatan Lengkiti, Provinsi Sumatera Selatan, 
nyamuk ini lebih bersifat zoofilik. Anopheles minimus betina di Indonesia lebih tertarik mengisap darah manusia dibandingkan darah hewan. Jenis nyamuk ini ditemukan di daerah kaki perbukitan. ${ }^{39}$

\section{Anopheles barbumbrosus}

Nyamuk An. barbumbrosus ditemukan di Kabupaten Raja Ampat pada ekosistem hutan dekat permukiman dan non hutan dekat permukiman dengan metode penangkapan ABT. ${ }^{11}$ Di Provinsi Sulawesi Tengah, An. barbumbrosus ditemukan di ekosistem hutan dekat dan jauh permukiman mengisap darah manusia. ${ }^{13}$ Anopheles barbumbrosus termasuk salah satu nyamuk hutan. Nyamuk ini menyerang manusia pada tempat dengan ketinggian 760-1.370 m dari permukaan laut. Anopheles barbumbrosus menunjukkan kecenderungan zoofilik. Nyamuk betinanya lebih senang beristirahat di kandang ternak daripada permukiman manusia. Aktivitas mengisap darahnya lebih banyak di luar ruangan daripada di dalam ruangan. Larva An. barbumbrosus lebih menyukai habitat yang mendapat sinar matahari langsung maupun tidak langsung, kolam air tergenang, genangan-genangan di sepanjang tepi sungai dan sawah, pernah juga ditemukan pada rawa dan kolam pemandian. ${ }^{39}$

\section{Anopheles farauti}

Nyamuk An. farauti dikonfirmasi sebagai vektor malaria di Papua yang dapat ditemukan mulai dari wilayah pantai sampai pegunungan. ${ }^{14}$ Anopheles farauti di Kabupaten Fakfak dan Manokwari ditemukan mengisap darah manusia di luar dan di dalam rumah, puncak kepadatan terjadi pada pukul 23.00-01.00, sedangkan di Kabupaten Raja Ampat nyamuk ini ditemukan mengisap darah manusia di luar rumah dan mengisap darah dengan umpan ternak, kepadatan nyamuk tertinggi terjadi pada pukul 18.00-19.00. Hasil koleksi larva nyamuk ini ditemukan di ketiak daun pisang, kobakan, tepi sungai, kolam dan rawa air tawar. ${ }^{11}$ Hasil penelitian di Kabupaten Biak Numfor pada ekosistem pantai dan di Kabupaten Asmat pada ekosistem rawa menunjukkan bahwa nyamuk $A n$. farauti paling banyak tertangkap pukul 18.00-19.00 dan terendah pukul 01.00-02.00. Hasil penelitian juga menunjukkan bahwa nyamuk An. farauti di ekosistem pantai dan rawa lebih banyak melakukan aktivitas mencari darah di luar rumah. Hasil ELISA pakan darah membuktikan bahwa nyamuk An. farauti di ekosistem pantai sebagian besar bersifat zoofilik, sedangkan di ekosistem rawa bersifat antropofilik. ${ }^{40}$ Habitat perkembangbiakan larva An. farauti antara lain pada perairan air tawar dan air payau serta menyukai paparan sinar matahari. Larva An. farauti memiliki toleransi terhadap kadar salinitas tinggi. Pada kondisi alami larva An. farauti ditemukan di rawa-rawa, kolam, laguna dimana terdapat vegetasi, parit, dan disepanjang tepi sungai. Beberapa penelitian yang pernah dilakukan menemukan larva $A n$. farauti di selokan atau parit, genangan air sementara, kolam ikan, kolam kangkung, bekas galian pasir, sumur, kubangan lumpur, dan genangan air pada kapal/perahu bekas yang sudah rusak. $^{6}$

\section{Anopheles punctulatus}

Anopheles punctulatus diketahui sebagai vektor malaria dan ditemukan positif $P$. vivax, $P$. malariae dan $P$. falcifarum di Papua bagian utara dan selatan baik di daerah pantai, dataran rendah dan dataran tinggi. Berdasarkan studi sebelumnya An. punctulatus juga ditemukan mengisap darah hewan dan manusia. Puncak kepadatan nyamuk ini terjadi pada pukul 22.00-23.00 dan dini hari pukul 02.00-03.00. ${ }^{13}$ Hasil penelitian di Jayapura An. punctulatus diketahui mengisap darah manusia di dalam dan luar rumah. ${ }^{11}$ Anopheles punctulatus aktif mengisap darah manusia dan hewan. Umumnya An. punctulatus akan beristirahat di dinding rumah atau semak-semak sekitar rumah. Anopheles punctulatus memiliki jarak terbang 0,4-2,4 $\mathrm{km}$ dari habitat perkembangbiakannya. Larva An. punctulatus berkembang biak di daerah kolam terbuka dengan air kolam yang jernih atau keruh tanpa adanya vegetasi air, genangan air terbuka, bekas tapak kaki hewan atau manusia, bekas jejak ban mobil, genangan air di ban bekas, dan pelepah pohon sagu. Anopheles punctulatus tidak ditemukan di daerah pantai air payau. Habitat larva An. punctulatus biasanya 
terpapar sinar matahari langsung dan dapat hidup pada suhu lingkungan habitat $42^{\circ} \mathrm{C} .{ }^{41}$

\section{Anopheles koliensis}

Nyamuk An. koliensis dapat ditemukan di Papua, Kepulauan Guadalcana dan Papua Nugini di daerah dengan ketinggian 800-1700 mdpl. Nyamuk dewasa $A n$. koliensis betina menyukai darah manusia dan darah hewan seperti anjing, babi dan burung, tetapi lebih menyukai mengisap darah manusia $(78 \%)$. Kebiasaan mengisap darah tergantung dari lokasi geografis. Nyamuk ini lebih banyak mengisap darah di luar rumah dan aktif istirahat di dalam rumah. Anopheles koliensis aktif di malam hari pada pukul 21.00-06.00 dengan frekuensi mengisap darah dan puncak kepadatan nyamuk dewasa bervariasi di tiap lokasi/daerah dan musim. Larva An. koliensis dapat ditemukan pada kolam rawa di sepanjang hutan, rawa hutan sagu, kolam permanen dan semi permanen dengan air dangkal, ditemukan pada habitat yang terpapar cahaya matahari langsung maupun tidak langsung. Larva nyamuk ini tidak ditemukan di air payau. ${ }^{41}$ Penelitian di Desa Dobonsolo, Kabupaten Jayapura, Papua, menemukan larva An. koliensis di selokan/parit, sumur, kolam air tergenang dengan vegetasi rumput, tumbuhan lumut dan kangkung. ${ }^{6,41}$

\section{Anopheles ludlowae}

Hasil studi sebelumnya An. Iudlowae telah terkonfimasi sebagai vektor malaria di Sulawesi Selatan dan Sulawesi Tengah. Anopheles ludlowae di hutan Provinsi Sulawesi Tengah $45,45 \%$ cenderung lebih senang mengisap darah manusia. Spesies ini ditemukan di ekosistem hutan dekat permukiman dan jauh permukiman. Berdasarkan studi di Taiwan An. Iudlowae diketahui sebagai vektor malaria walaupun bukan vektor utama. ${ }^{13}$ Anopheles ludlowae ditemukan di Kabupaten Raja Ampat dengan menggunakan perangkap hewan ternak. $^{11}$

\section{Anopheles bancrofti}

Nyamuk An. bancrofti yang ditemukan di Provinsi Papua tertangkap pada ekosistem hutan dekat dan jauh permukiman. Nyamuk ini senang mengisap darah manusia dan juga hewan, tetapi lebih cenderung menyukai darah manusia. Total penangkapan nyamuk $82,23 \%$ ditemukan mengisap darah orang dengan metode man landing collection dan 17,53\% ditemukan mengisap darah hewan dengan metode ABT dan around cattle collection. ${ }^{13}$

\section{Anopheles longirostris}

Nyamuk An. longirostris merupakan salah satu spesies Australasia. Hasil pemeriksaan patogen di laboratorium, An. longirostris positif Plasmodium di Kabupaten Manokwari, Provinsi Papua Barat. Nyamuk ini ditemukan di ekosistem hutan dekat dan jauh permukiman mengisap darah manusia di luar rumah. ${ }^{11} \mathrm{Di}$ Provinsi Papua, An. longirostris hanya ditemukan tertangkap dengan metode man landing collection pada ekosistem hutan jauh permukiman. ${ }^{13}$ Anopheles longirostris telah dikonfirmasi sebagai vektor malaria di Papua. $^{14}$

\section{Anopheles hinesorum}

Nyamuk An. hinesorum telah terbukti positif mengandung $P$. falcifarum. Nyamuk ini bersifat zoofilik dan ditemukan mengisap darah hewan ternak. ${ }^{15}$ Anopheles hinesorum merupakan vektor yang penting dari $P$. malariae, $P$. vivax dan $P$. falcifarum di Papua Nugini. ${ }^{42}$ Di Kepulauan Solomon, An. hinesorum ditemukan mengisap darah manusia meskipun dalam jumlah yang kecil. ${ }^{43}$ Anopheles hinesorum sebelumnya sering dilaporkan mengisap darah hewan dan bukan sebagai vektor malaria manusia, sampai akhirnya penelitian menemukan DNA $P$. falcifarum di kepala dan dada $A n$. hinesorum, membuat spesies ini rentan terhadap infeksi $P$. falcifarum. Meskipun begitu nyamuk ini jarang mengisap darah manusia, dan tidak mungkin dapat mempertahankan penularan malaria. ${ }^{44}$

\section{Anopheles peditaeniatus}

Nyamuk An. peditaeniatus di Kabupaten Manokwari, Papua Barat, ditemukan pada ekosistem hutan dekat dan jauh permukiman, dan juga ditemukan pada ekosistem non hutan dekat permukiman. Nyamuk ini tertangkap dengan metode ABT. ${ }^{11}$ Anopheles peditaeniatus merupakan Anopheles yang dominan di Kabupaten Merauke, Papua. Aktivitas mengisap darah An. peditaeniatus dapat dijumpai di dalam 
rumah, aktivitas dimulai pada pukul 22.00 dan menjelang pagi pukul 03.00. Di luar rumah aktivitas terjadi pada pukul 22.00, 24.00 dan menjelang pagi pukul 04.00. Anopheles peditaeniatus baru aktif menjelang tengah malam hingga menjelang pagi. Aktivitas An. peditaeniatus di ternak sapi terjadi sepanjang malam, puncak aktivitas yaitu pukul 21.00, 23.00, 01.00 dan pukul 04.00. Larva An. peditaeniatus ditemukan di sawah, kolam tidak produktif, parit dan rawa-rawa. Tipe habitat $A n$. peditaeniatus yang ditemukan di Thailand yaitu tepi sungai, kolam, parit, rawa, sawah, dan kolam ikan. ${ }^{45}$

\section{Anopheles meraukensis}

Nyamuk An. meraukensis ditemukan pada ekosistem hutan dekat dan jauh permukiman di Provinsi Papua. Nyamuk ini lebih cenderung mengisap darah manusia dibandingkan hewan ternak. ${ }^{13}$ Anopheles meraukensis merupakan Anopheles yang sangat spesifik yang hanya ditemukan di wilayah Papua bagian Selatan. Anopheles meraukensis pernah ditemukan di dalam rumah di Kumbe, Merauke, walaupun sebagai antropofilik, An. meraukensis belum diketahui perannya sebagai vektor. Larva An. meraukensis ditemukan di kolam yang tidak terpakai, di kolam tanah, saluran irigasi, parit dengan sedikit serasah, rawa, bekas jejak roda kendaraan yang ditumbuhi ganggang, serta di sawah yang baru dialiri air dan seringkali larva ditemukan pada habitat yang berair segar tanpa tanaman peneduh apapun sehingga langsung terpapar sinar matahari. ${ }^{45}$

\section{Anopheles annulipes}

Nyamuk An. annulipes ditemukan di Kabupaten Raja Ampat, Papua Barat pada ekosistem hutan dan non hutan dengan metode penangkapan menggunakan umpan ternak. ${ }^{11}$ Anopheles annulipes yang tersebar di Australia diketahui tidak mengisap darah manusia dan termasuk zoofilik. Anopheles annulipes merupakan spesies dataran tinggi yang umum yang berada pada ketinggian diatas $1000 \mathrm{~m}^{46}$

\section{Anopheles aitkenii}

Nyamuk An. aitkenii ditemukan di Kabupaten Fakfak, Papua Barat pada ekosistem pantai mengisap darah manusia di luar rumah. ${ }^{11}$ Penelitian yang dilakukan di Purworejo, An. aitkenii ditemukan pada pukul 21.00, pukul 03.00 dan pukul 04.00. Habitat nyamuk ini yaitu di perkebunan, lahan basah pertanian, hutan, ladang, gunung, bukit atau dataran. Habitat perkembangbiakan utama yaitu sungai yang alirannya tidak terus menerus dan mata air. Peran $A n$. aitkenii sebagai vektor untuk penularan malaria masih dalam proses peninjauan. Meskipun riwayat dari spesies ini tidak bertindak sebagai vektor, potensi perubahan untuk menjadi vektor masih memungkinkan. ${ }^{47}$

\section{KESIMPULAN}

Nyamuk Anopheles yang sudah terkonfirmasi sebagai vektor malaria di Provinsi NTT yaitu An. barbirostris, An. subpictus, An. sundaicus, An. flavirostris, dan An. minimus, di Provinsi Papua yaitu An. farauti, An. punctulatus dan An. longirostris, sedangkan di Provinsi Papua Barat yang sudah terkonfirmasi yaitu $A n$. longirostris. Kesukaan mengisap darah Anopheles bersifat antropofilik dan zoofilik namun lebih cenderung bersifat antropofilik, perilaku mengisap darah dan istirahat cenderung eksofagik dan eksofilik. Kebanyakan nyamuk Anopheles mulai muncul pukul 18.00. Habitat perkembangbiakan banyak ditemukan di sawah, kubangan, bekas kolam, rawa, selokan, mata air, laguna, aliran air, pantai, ketiak daun pisang, tepi sungai, sumur, pelepah pohon sagu, dan berbagai macam genangan air.

\section{SARAN}

Informasi tentang spesies Anopheles di masing-masing daerah harus terus diperbaharui terutama informasi tentang spesies Anopheles yang menjadi vektor malaria di daerah tersebut, agar upaya pengendalian vektor malaria dapat menyesuaikan dengan bionomik dari vektor tersebut dan upaya pengendalian pun dapat lebih optimal. Perlu juga adanya pemetaan vektor malaria, agar diketahui apakah nyamuk Anopheles di wilayah Indonesia bagian timur sudah mulai menyebar ke wilayah Indonesia bagian barat begitupun sebaliknya atau masih tetap. Penelitian konfirmasi tentang vektor malaria juga perlu 
dilakukan untuk mengetahui apakah ada pertambahan jumlah vektor malaria di Indonesia.

\section{KONTRIBUSI PENULIS}

Kontribusi penulis pada artikel ini yaitu kontributor utama adalah VM, kontributor anggota adalah TW.

\section{DAFTAR PUSTAKA}

1 Purba IE, Hadi UK, dan Hakim L. Analisis Pengendalian Malaria di Provinsi Nusa Tenggara Timur dan Rencana Strategis Untuk Mencapai Eliminasi Malaria. Spirakel. 2016. 8(2): 18-26.

2 Hakim L, Wahono T, Ruliansyah A, Kusnandar AJ. Potensi Kemunculan Kembali Malaria di Kabupaten Pangandaran. Aspirator. 2018. 10(1): 37-48.

3 Purnama SG. Diktat Pengendalian Vektor. Program Studi IImu Kesehatan Masyarakat. Fakultas Kedokteran. Univeritas Udayana. 2017.

4 Kementerian Kesehatan RI. Profil Kesehatan Indonesia Tahun 2018. Jakarta: Kementerian Kesehatan RI. 2019

5 Budiyanto A, Ambarita LP dan Salim M. Konfirmasi Anopheles sinensis dan Anopheles vagus Sebagai Vektor Malaria di Kabupaten Muara Enim Provinsi Sumatera Selatan. Aspirator. 2017. 9(2): 51-60

6 Sandy S. Karakteristik Habitat Anopheles punctulatus group Sebagai Vektor malaria di Papua. Jurnal Buski (Jurnal Epidemiologi dan Penyakit Bersumber Binatang). 2015. 5(3): 126131.

7 Ariati J, Ibrahim IN, dan Perwitasari D. Sebaran Habitat Perkembangbiakan Larva Anopheles spp di Kecamatan Bula, Kabupaten Seram Bagian Timur, Provinsi Maluku. Jurnal Ekologi Kesehatan. 2014. 13(1): 10-22.
8 Rahmawati E, Hadi UK, dan Soviana S. Keanekaragaman Jenis dan Perilaku Menggigit Vektor Malaria (Anopheles spp) di Desa Lifuleo, Kecamatan Kupang Barat, Kabupaten Kupang, Nusa Tenggara Timur. Jurnal Entomologi Indonesia. 2014. 11(2): 5364.

9 Sopi IIPB dan Kazwaini M. Bionomik Anopheles spp di Desa Konda Maloba, Kecamatan Katikutana Selatan, Kabupaten Sumba Tengah, Provinsi NTT. Jurnal Ekologi Kesehatan. 2014. 13(3): 240-254.

10 Kazwaini M dan Mading M. Jenis dan Status Anopheles spp Sebagai Vektor Potensial Malaria di Pulau Sumba Provinsi Nusa Tenggara Timur. Jurnal Ekologi Kesehatan. 2015. 14(2): 96-105.

11 Setiyaningsih R, Prihatin MT, Mujiyono, Garjito TA, dan Widiarti. Distribusi Vektor dan Potensi Penularan Malaria di Papua Barat Pada Berbagai Ekosistem. Vektora. 2018.10(1): 1-12

12 Oktavian A. Konfirmasi Vektor Malaria Pada Nyamuk Anopheles di Dua Kabupaten di Provinsi Papua Barat. [Laporan Penelitian]. Balai Litbang Biomedis Papua. Badan Litbang Kesehatan Kemenkes RI. 2014.

13 Setiyaningsih $\mathrm{R}$, Yanti $\mathrm{AO}$, Lasmiati, Mujiyono, Prihatin MT, dkk. Keanekaragaman Anopheles dalam Ekosistem Hutan dan Resiko Terjadinya Penularan Malaria di Beberapa Provinsi di Indonesia. Media Litbangkes. 2019. 29(3): 243-254.

14 Kawulur HSI, Ayomi I, Suebu M, Rokhmad MF, dan Pardi MR. Pengaruh Faktor Klimatik Terhadap Kepadatan Nyamuk Anopheles farauti di Ekosistem Pantai dan Rawa Provinsi Papua. Jurnal Biologi Papua. 2019. 11(2): 7279.

15 St. Laurent B, Supratman S, Asih PBS, Bretz D, Mueller J, dkk. Behaviour 
and Molecular Identifiation of Anopheles Malaria Vectors in Jayapura District, Papua Province, Indonesia. Malaria Journal. 2016. 15:192.

16 Hanida SF. Potensi Tinggi Faktor Lingkungan Fisik dan Biologis Terjadinya Penularan Malaria di Wilayah Kerja Puskesmas Pandean Trenggalek. Jurnal Kesehatan Lingkungan. 2018. 10(1): 82-91.

17 Wijaya E, Hermansyah, Yusuf R. Faktor-faktor yang Berhubungan Dengan Kejadian Malaria Berdasarkan Model Community As Partner Pada Pekerja Tambang Emas Gunong Ujeun. Jurnal IImu Keperawatan. 2017. 5(2): 113.

18 Iryani K. Hubungan Anopheles barbirostris Dengan Malaria. Jurnal Matematika, Sains, dan Teknologi. 2011. 12(1): 18-29.

19 Maksud M. Aspek Perilaku Penting Anopheles vagus dan Potensinya Sebagai Vektor Malaria di Sulawesi Tengah : Suatu Telaah Kepustakaan. Jurnal Vektor Penyakit. 2016. 10(2): 3338.

20 Ndoen E, Wild C, Dale P, Sipe N dan Dale M. Relationships Between Anopheline mosquitoes and Topography in West Timor ang Java, Indonesia. Malaria Journal. 2010. 9: 242.

21. Laumalay HM. Perilaku Menghisap Darah An. Barbirostris di Lokasi Tambak Ikan Bandeng dan Kampung Salupu Desa Tuadale Kabupaten Kupang Tahun 2010. Jurnal Ekologi Kesehatan. 2013. 12(1): 72-78.

22. Noshirma M, Willa RW, dan Adnyana NWD. Beberapa Aspek Perilaku Nyamuk An. barbirostris di Kabupaten Sumba Tengah Tahun 2011. Media Litbang Kesehatan. 2012. 22(4): 161166.
23. Hernawan $A D$ dan Hamal S. Bionomik Nyamuk Anopheles spp di Desa Sumare dan Desa Tapandullu Kecamatan Simboro Kabupaten Mamuju Provinsi Sulawesi Barat Tahun 2011. Aspirator. 2011. 3(2): 64-71.

24. Dhewantara PW, Astuti EP, dan Pradani FY. Studi Bioekologi Nyamuk Anopheles sundaicus di Desa Sukaresik Kecamatan Sidamulih Kabupaten Ciamis. Buletin Penelitian Kesehatan. 2013. 41(1): 26-36.

25. Sopi IIPB. Beberapa Aspek Perilaku Anopheles sundaicus di Desa Konda Maloba Kecamatan Katikuna Selatan Kabupaten Sumba Tengah. Aspirator. 2014. 6(2): 63-72.

26. Adnyana NWD. Beberapa Aspek Bionomik Anopheles sp di Kabupaten Sumba Tengah, Provinsi Nusa Tenggara Timur. Media Litbang Kesehatan. 2011. 21(2): 62-70.

27. Shinta, Sukowati S, Pradana A, Marjianto dan Marjana P. Beberapa Aspek Perilaku Anopheles maculatus Theobald di Pituruh, Kabupaten Purworejo, Jawa Tengah. Buletin Penelitian Kesehatan. 2013. 41(3): 131141.

28 Alfiah S, TB Damar, Mujiyono, DH Farida. Pemilihan Hospes Anopheles sp di Kabupaten Magelang, Jawa Tengah. Media Litbang Kesehatan. 2008. 28(4): 185-192.

29 Munif A. Nyamuk Vektor malaria dan Hubungannya Dengan Aktivitas Kehidupan Manusia di Indonesia. Aspirator. 2009. 1(2): 94-102.

30 Barodji, T.B Damar, Boesri $H$, Sudini dan Sumardi. Bionomik Vektor dan Situasi Malaria di Kecamatan Kokap, Kabupaten Kulonprogo, Yogyakarta. Jurnal Ekologi Kesehatan. 2003. 2(2): 209-216.

31. Leaua DJ. Sebaran Kepadatan Larva dan Nyamuk Anopheles spp Penyebab 
Penyakit Malaria di Desa Kumo Kecamatan Tobelo Kabupaten Halmahera Utara Provinsi Maluku Utara [Tesis]. Makasar: Universitas Hasanudin. 2013.

32. Prastowo D, Widiarti, Garjito TA. Bionomik Anopheles spp Sebagai Dasar Pengendalian Vektor Malaria di Kabupaten Kebumen Jawa Tengah. Vektora. 2018. 10(1): 25-36.

33. Mading $M$ dan Kazwaini $M$. Ekologi Anopheles spp di Kabupaten Lombok Tengah. Aspirator. 2014. 6(1): 13-20.

34. Setiyaningsih $R$ dan Widiarti.Studi Bioekologi Vektor Malaria di Kabupaten Kebumen Jawa Tengah. Vektora. 2014. 6(2): 52-58.

35. Sambuaga JVI, Duka RS, dan Hermanus D. Kepadatan (Man Biting Rate) Nyamuk Anopheles Di Desa Ranoketang Tua, Kecamatan Amurang Kabupaten Minahasa Selatan. Jurnal Kesehatan Lingkungan. 2019. 9(2): 100-109.

36. Adnyana NWD dan Wila RW. Fauna Anopheles sp. di Kabupaten Sumba Barat Daya. Jurnal Ekologi Kesehatan. 2011. 11(3): 211-219.

37. Sucipto CD. Studi Vektor Malaria di Desa Emparu dan Mangat Baru Kecamatan Dedai Kabupaten Sintang Provinsi Kalimantan Barat. Jurnal Medikes. 2014. 1(2): 95-106.

38. Muhammad R, Soviana S, Hadi UK. Keanekaragaman Jenis dan Karakteristik Habitat Nyamuk Anopheles spp. di Desa Datar Luas, Kabupaten Aceh Jaya, Provinsi Aceh. Jurnal Entomologi Indonesia. 2015. 12(3): 139-148.

39. Mahdalena $\mathrm{V}$ dan Ni'mah T. Ekologi Nyamuk Anopheles spp. di Kecamatan Lengkiti, Ogan Komering Ulu, Sumatera Selatan Tahun 2004-2015. Spirakel. 2016. 8(2): 27-36.
40. Kawulur $\mathrm{H}$, Soesilohadi $\mathrm{RCH}$, Hadisusanto S, dan Trisyono A. Perilaku Vektor Malaria Anopheles farauti Laveran (Diptera: Culicidae) di Ekosistem Pantai (Kabupaten Biak Numfor) dan Ekosistem Rawa (Kabupaten Asmat) Propinsi Papua. BIOMA. 2015. 17(1): 34-40.

41. Sandy S. Bionomi Vektor Malaria Kelompok Anopheles punctulatus (Anopheles farauti, Anopheles koliensis, Anopheles punctulatus) di Provinsi Papua. Balaba. 2014. 10(1): 47-52.

42 Cooper RD, Waterson DGE, Frances SP, Beebe NW, Pluess B, Sweeney AW. Malaria vectors of Papua New Guinea. International Journal For Parasitology. 2009. 39(13): 1495-1501.

43 Bugoro $H$, Iro'ofa $C$, Mackenzie D, Apairamo A, Hevalao W, Corcoran S, et al. Changes in vector species composition and current vector biology and behaviour will favour malaria elimination in Santa Isabel Province, Solomon Islands. Malaria Journal. 2011. 10:287.

44. Burkot TR, Bugoro $H$, Apairamo $A$, Cooper RD, Echeverry DF, dkk. Spatial-Temporal Heterogeneity in Malaria Receptivity Is Best Estimated By Vector Biting Rates In Areas Nearing Elimination. Parasites \& Vectors. 2018. 11: 606.

45. Shinta dan Marjana P. Distribusi dan Perilaku Vektor Malaria di Kabupaten Merauke, Papua. Buletin Penelitian Kesehatan. 2015. 43(4): 219-230.

46. Beebe NW, Russell TL, Burkot TR, Lobo NF dan Cooper RD. The Systematics and Bionomics of Malaria Vectors in the Southwest Pacific.[internet]. 2013. [Diakses 23 Juni 2020]. Tersedia di: https://researchonline.jcu.edu.au/28195 11/Beebe 2013 The systematics and bionomics of malaria vectors.pdf. http://dx.doi.org/10.5772/55999. 
47. Rahardjo M, HD Yusniar dan Ginandjar P. The New Spesies Anopheles aitkeni as the Threat of Malaria in Indonesia. Indian Journal of Public Health Research \& Development. 2018. 9(4): 206-210. 